\title{
SELECTION CHARTS FOR STRUCTURAL STEELS REGARDiNG Design Criteria AND Trending Properties
}

\author{
Petar Tasic, Ismar Hajro, Damir Hodzic \& Adi Pandzic
}
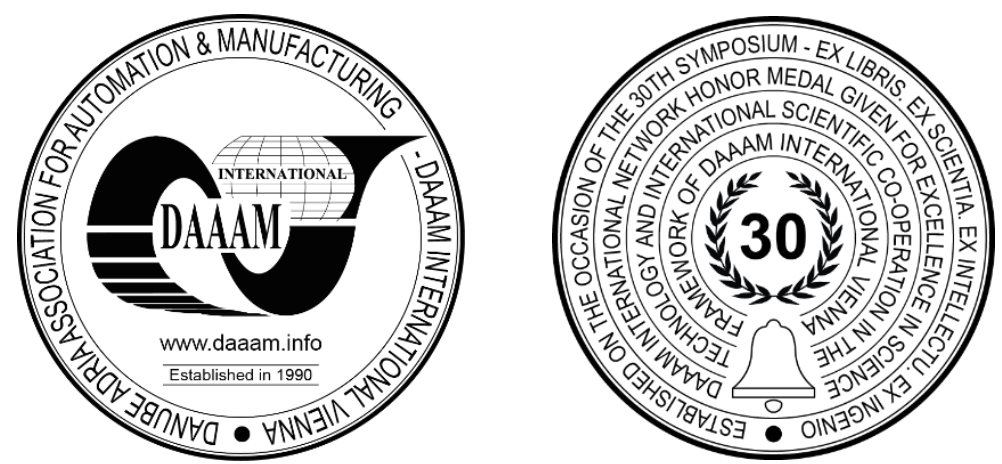

This Publication has to be referred as: Tasic, P[etar]; Hajro, I[smar]; Hodzic, D[amir] \& Pandzic, A[di] (2020). Selection Charts for Structural Steels Regarding Design Criteria and Trending Properties, Proceedings of the 31st DAAAM International Symposium, pp.0453-0458, B. Katalinic (Ed.), Published by DAAAM International, ISBN 9783-902734-29-7, ISSN 1726-9679, Vienna, Austria DOI: $10.2507 / 31$ st.daaam.proceedings.063

\begin{abstract}
Existence of standardized materials and product standards for various products gives confidence in complete material selection process. In case of welded steel products, respective product standards clearly define requirements for design and fabrication. Among many properties, four are mostly considered: strength, ductility, toughness, and weldability. Nowadays products are more demanding than ever, and it is not possible to consider single property anymore, but two or even three of them. In such cases, selection charts are used, making material selection easier. This paper provides selection charts and corresponding design criteria defined in welded product standards for selected structural steel grades. Values presented in selection charts are acquired through own researches, as well as from available literature. Considered structural steels are grades with yield strength from 355 to $960 \mathrm{MPa}$, available in three mayor delivery conditions: normalized, thermo-mechanically treated, and quenched and tempered.
\end{abstract}

Keywords: material selection; selection chart; steel; strength.

\section{Introduction}

Material selection is dynamic process, since there are constant changes in availability of material(s), design criteria, as well as purchase price. However, existence of standardized materials and respective product standards gives confidence and reliability in entire selection process. In the case of welded steel products, four key properties (i.e. design parameters) are recognized by product standards: strength, ductility, toughness, and weldability. [1] The constant increase in demands regarding mechanical properties with the requirements for low costs are forcing manufacturers to create new types of materials that can achieve both high strength and good ductility. [2]

Steel strength is the most important and demanding mechanical property. Increased strength provides lighter welded products, due to decrease in necessary dimensions. Therefore, such products have reduced price as well. The principal indication of strength for engineering purpose is yield strength $(Y)$, while is some cases tensile strength $(T)$ may be utilized. When higher steel strength grade is selected (with higher $Y$ ), less required thickness(es) can be achieved. However, this can lead to additional requirements for sufficient resistance to buckling, deflection and vibration. This can be solved by increasing cross-section (e.g. in the case of fatigue loading, where high strength steels could not be used) or increasing stabilizing weight of product (such as for seismic or wind loads). [1] 
Steel ductility is always required to be within designated range, providing ductile behaviour of product or its components in specific load scenarios, as well as for provision of formability by cold or hot forming processes. [1] Also, certain level of ductility is required to enable ductile resistance behaviour in the case of specific design loads, e.g. creep [3]. Contrary, material may behave in rather undesirable manner which can lead to fatal failures [4]. In this paper, measure of ductility is represented not only by the elongation after fracture $(A)$, but with yield to tensile strength ratio $(Y / T)$. [5]

Steel toughness must be considered regarding avoidance of brittle fracture or high rate of crack propagation, at given minimum design temperature. This is particularly important whenever product will be used at low ambiental temperatures or be exposed to low temperatures during regular usage. Minimal design temperature must be determined and considered during material selection, since most structural steels exhibit transition temperature from ductile to brittle fracture [6], [7]. Disregard of this criteria during material selection could lead to sudden product failures in exploitation.

Steel weldability is property which must be considered through entire development process of welded product, from design to selling. Weldability could be described as suitability of base metal for application of selected welding technology with provision of minimum required design mechanical properties (i.e. strength and toughness) and avoidance of any unallowable imperfections within welded joints. Weldability is mostly evaluated through chemical composition of base metal, while for structural unalloyed and low alloyed steels through so called carbon equivalent (CEV). [8], [9]

This paper presents selection charts comprising different structural steels grades, with yield strength varying from 355 to $960 \mathrm{MPa}$. Charts are based on important mechanical properties and weldability. Considered structural steels are available in three mayor delivery conditions: normalized, thermo-mechanically treated, and quenched and tempered. The purpose of research is to check whether delivering condition has influence on analysed properties of structural steels. Significant number of researches is done regarding proper selection of structural steels for specific applications, such as for civil buildings [6], [10], cranes, [11], wind power plants [12], [13], bridges [14], pipelines, pressure vessels [15], [16], [17] and offshore structures [18]. There also are many guidelines, product codes and standards available regarding specific products, as well as legal documents treating proper choice of steel for particular purpose.

\section{Analysed steels}

Scope of this study are structural steels standardized trough series of European standards (such as EN 10025 and EN 10216) and International standards (such as ISO 3183) for plates and pipes, with strength grades from 355 to 960 , where given numbers represent minimum guaranteed yield strength $(Y$, in $\mathrm{MPa})$. Included structural steels can be delivered in various conditions: as-rolled (AR), normalized $(\mathrm{N})$, thermo-mechanically treated $(\mathrm{M})$, and quenched and tempered (QT). Table 1 gives an overview of their mechanical properties and chemical characteristics.

\begin{tabular}{|c|c|c|c|c|}
\hline \multirow{2}{*}{$\begin{array}{l}\text { Guaranteed } \\
\text { properties }\end{array}$} & \multicolumn{4}{|c|}{ Delivery condition } \\
\hline & $\begin{array}{c}\text { AR } \\
\text { EN 10025-2 }\end{array}$ & $\begin{array}{c}\mathrm{N} \\
\text { EN 10025-3, ISO } 3183\end{array}$ & $\begin{array}{c}\text { M } \\
\text { EN 10025-4, ISO } 3183\end{array}$ & $\begin{array}{c}\text { QT } \\
\text { EN 10025-6, ISO } 3183\end{array}$ \\
\hline$Y(\mathrm{MPa})$ & $235-460$ & $275-460$ & $275-460$ & $460-960$ \\
\hline$A(\%)$ & $26-20$ & $24-17$ & $24-17$ & $17-10$ \\
\hline $\mathrm{KV}(\mathrm{J})$ & $\begin{array}{c}27 \mathrm{~J} @ 20{ }^{\circ} \mathrm{C} \text { to } \\
27 \mathrm{~J}(40 \mathrm{~J}) @-20{ }^{\circ} \mathrm{C}\end{array}$ & $\begin{array}{c}40 \mathrm{~J} @-20^{\circ} \mathrm{C} \text { to } \\
27 \mathrm{~J} @-50{ }^{\circ} \mathrm{C}\end{array}$ & $\begin{array}{c}40 \mathrm{~J} @-20^{\circ} \mathrm{C} \text { to } \\
27 \mathrm{~J} @-50{ }^{\circ} \mathrm{C}\end{array}$ & $\begin{array}{c}30 \mathrm{~J} @-20^{\circ} \mathrm{C} \text { to } \\
30 \mathrm{~J} @-60{ }^{\circ} \mathrm{C}\end{array}$ \\
\hline $\mathrm{CEV}_{\max }$ & $0.35-0.47$ & $0.40-0.53$ & $0.34-0.45$ & $0.47-0.82$ \\
\hline $\begin{array}{l}\text { Chemical } \\
\text { composition }\end{array}$ & $\begin{array}{l}\text { Unalloyed } \\
\text { C-Mn }\end{array}$ & $\begin{array}{l}\text { Unalloyed } \\
\text { C-Mn }\end{array}$ & $\begin{array}{l}\text { Micro-alloyed } \\
\mathrm{Nb}, \mathrm{Ti}, \mathrm{V}\end{array}$ & $\begin{array}{c}\text { Low-alloyed } \\
\mathrm{Cr}, \mathrm{Ni}\end{array}$ \\
\hline
\end{tabular}

Table 1. Properties regarding delivery condition of structural steels included in this study

Table 2 gives overview of four principal design criteria covered and included in this study.

\begin{tabular}{|c|c|c|c|}
\hline Material property & Design standard & Criteria & Remarks \\
\hline Strength & \multirow{4}{*}{$\begin{array}{l}\text { Eurocode } 3 \text { (Steel structures) } \\
\text { EN } 14015 \text { (Storage tanks) } \\
\text { EN } 13445 \text { (Pressure vessels) }\end{array}$} & $\begin{array}{c}Y / T_{\max }=0.91, \text { up to } 460 \\
Y / T_{\max }=0.95, \text { for } 460-690 \\
Y / T_{\max }=0.93, \text { for gas pipes }\end{array}$ & $\begin{array}{l}\text { Depending on steel strength } \\
\text { grade (valid for 235-690) and } \\
\text { type of welded product }\end{array}$ \\
\hline Ductility & & $\begin{array}{c}A_{\min }=15 \%, \text { up to } 460 \\
A_{\min }=10 \%, \text { for } 460-690 \\
A_{\min }=14 \%, \text { for vessels }\end{array}$ & $\begin{array}{l}\text { Depending on steel strength } \\
\text { grade and type of welded } \\
\text { product }\end{array}$ \\
\hline Toughness & & \multicolumn{2}{|c|}{$\begin{array}{l}\text { Depending on stress level, minimum design temperature and } \\
\text { thickness. The maximum thickness is defined regarding steel } \\
\text { toughness grade and minimum design temperature. }\end{array}$} \\
\hline Weldability & & $\begin{array}{l}\text { No principal limits. } \\
\text { The lower the better. }\end{array}$ & $\begin{array}{l}\text { Regarding to CEV and EN } \\
1011-2 \text { recommendation(s). }\end{array}$ \\
\hline
\end{tabular}

Table 2. Considered design criteria 
Considered design criteria given in Table 2 include strength ( $T$ denotes tensile strength in MPa), ductility ( $A$ denotes elongation after fracture in \%), toughness (KV denotes impact toughness in J) and weldability (CEV according to EN 1011-2). All data has been taken from corresponding welded product's design standards. [1], [5], [6], [7]

\section{Results and discussion}

Results considered in this analysis comprise various experimental results presented in literature [4], [5], [12], [13], [15], [17] as well results of some own researches [7], [8], [9]. First selection chart, shown in Fig. 1, presents dependence of ductility $(A)$ on yield stress $(Y)$. As possible to see, with increase of strength, ductility has significant drop, while ductility for high-strength steels (more than 1,000 MPa) is close to limits defined and set by design codes and standards $\left(A_{\text {limit }}=10-15 \%\right)$.

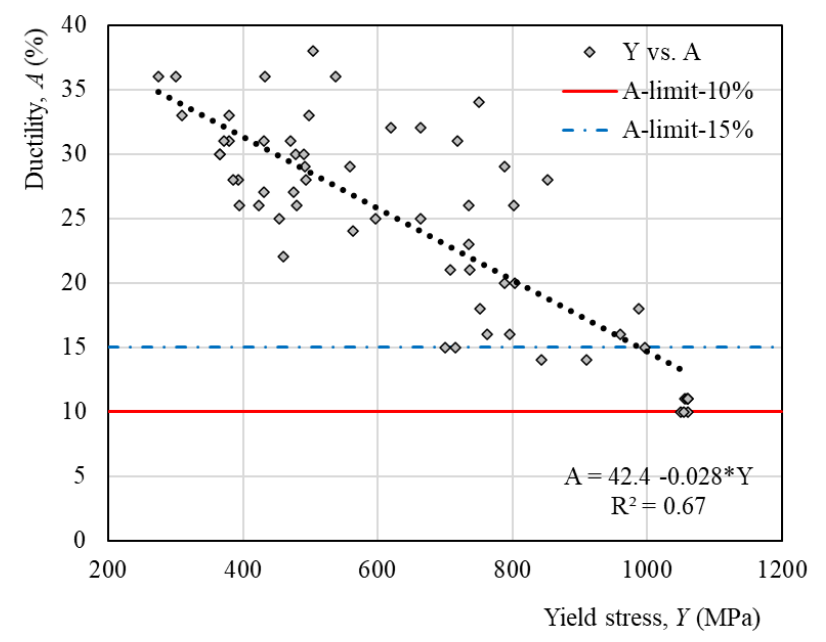

Fig. 1. Ductility $(A)$ as function of yield stress $(Y)$

Second selection chart, shown in Fig. 2, shows yield stress to tensile strength ratio $(Y / T)$ dependence on yield stress $(Y)$. Similarly, as shown for ductility in Fig. 1, the higher is steel strength the more unfavourable is yield stress to tensile strength ratio $(Y / T)$, and closer to design criteria limits set by product codes or standards. Maximum value of ratio $Y / T_{\text {limit }}$ is usually defined as $0.91-0.95$, due to safety of product.

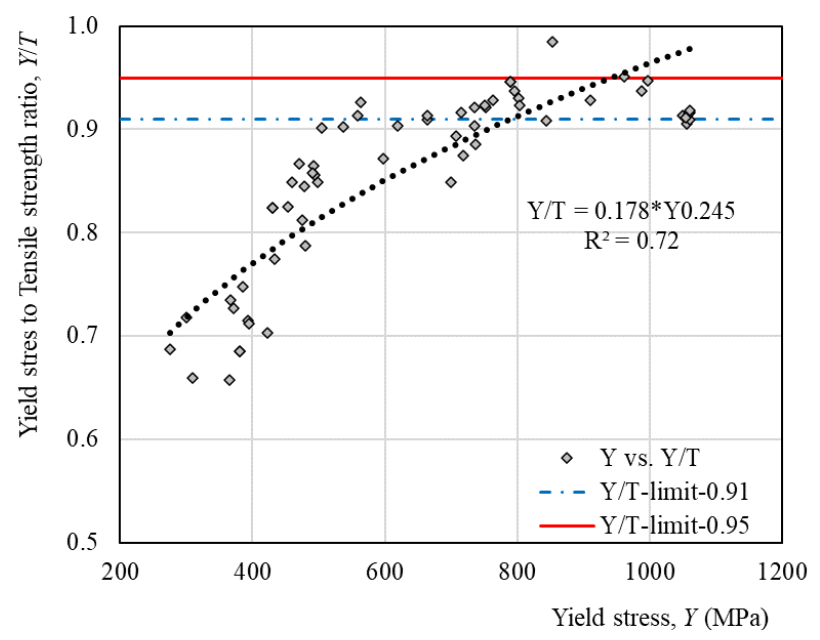

Fig. 2. Yield stress to tensile strength ratio $(Y / T)$ as function of yield stress $(Y)$

Third selection chart, shown in Fig. 3, shows dependence of impact toughness (KV) on steel strength (represented as yield stress, $Y$ ). In this case, dependence is provided with consideration of delivery condition of steel, since toughness can vary significantly for different microstructures (i.e. delivery conditions). Steels delivered in normalized (N) and quenched and tempered $(\mathrm{Q})$ condition exhibit relatively uniform decrease of toughness as strength is increased. However, thermomechanically treated steels $(\mathrm{M})$ have maximum toughness for strength range of 460-600 MPa. It is important to note that chart shown in Fig. 3 is valid for normal ambient temperature (i.e. $+20{ }^{\circ} \mathrm{C}$ ). More detailed overview may require data of toughness dependence on temperature, with consideration of so-called transition temperature(s) $\left(T_{\mathrm{T}}\right)$. Such overview is provided later, in Fig. 6. 


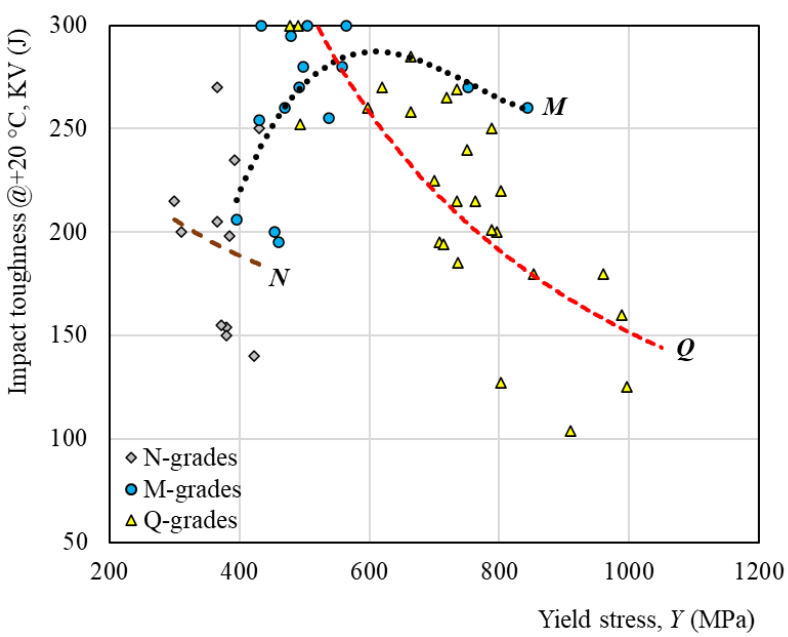

Fig. 3. Impact toughness (KV) as function of yield stress $(Y)$

Selection chart shown in Fig. 4 shows carbon equivalent (CEV) dependence on strength level (represented as yield stress, $Y$ ). Dependence is again provided with consideration of delivery condition of steel, denoted as N, M and Q. As possible to see, thermo-mechanically treated (M) structural steels have the lowest CEV values for specified yield strength.

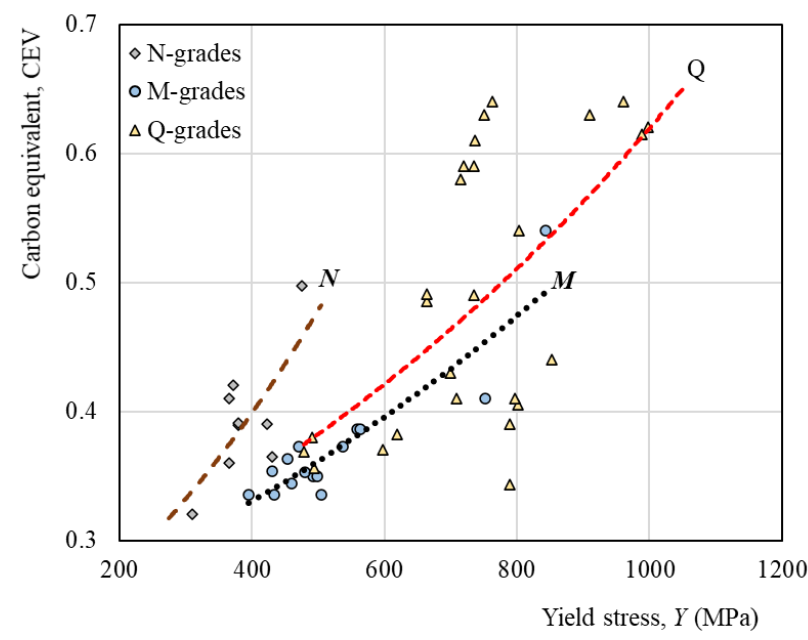

Fig. 4. Carbon equivalent (CEV) as function of yield stress $(Y)$

Interesting overview is shown in Fig. 5, which gives impact toughness (KV) dependence on carbon equivalent (CEV).

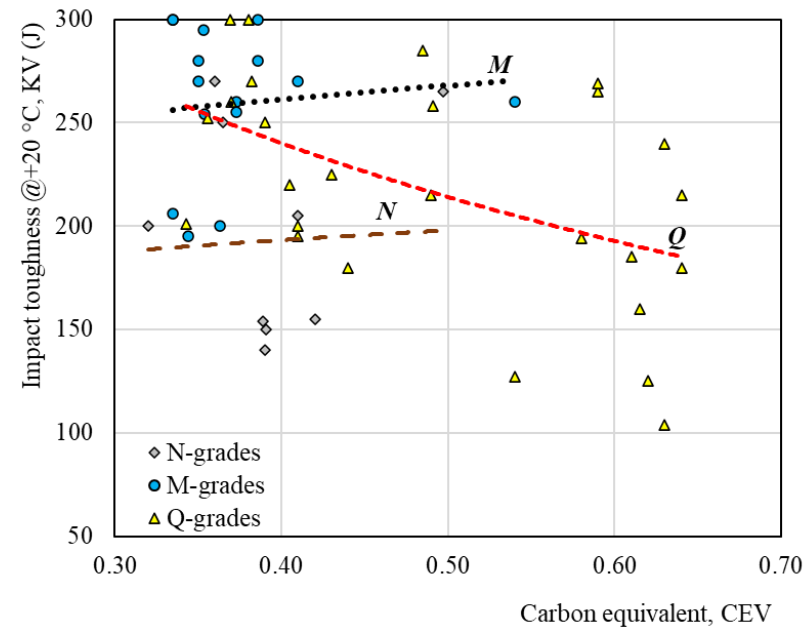

Fig. 5. Impact toughness (KV) as function of carbon equivalent (CEV) 
Structural steels that could be considered as superior are those delivered in thermo-mechanically treated condition (M), with highest values of toughness (KV), and increased values of carbon equivalent and strength (as shown in Fig. 4). However, structural steel selection regarding toughness requirements should consider other several important variables, such as maximum thickness, minimum design temperature and design stress level.

Better outlook of steel toughness is provided in Fig. 6 where impact toughness dependence on testing temperature is shown for structural steels of various strength levels and delivery conditions [7], [12], [17].

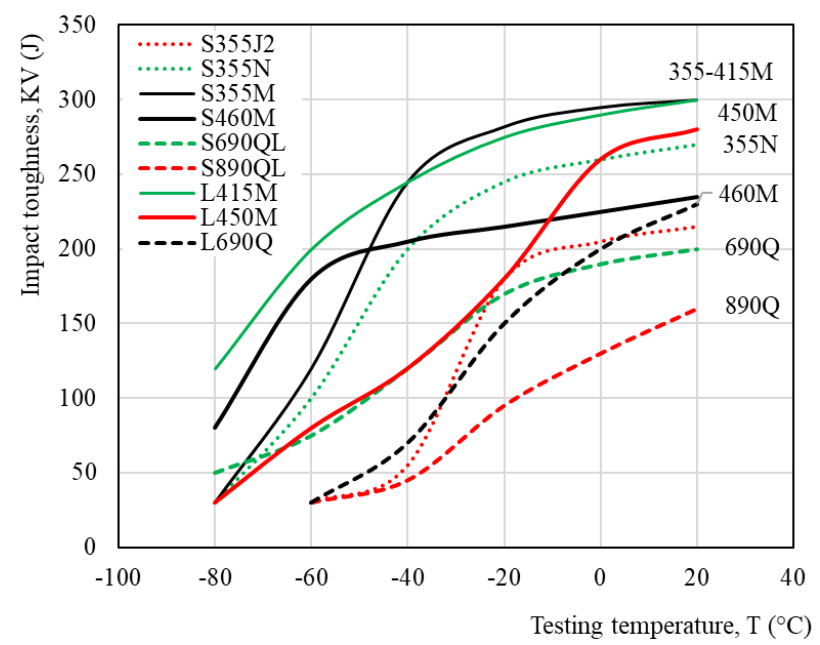

Fig. 6. Dependence of impact toughness on testing temperature for various grades and delivery conditions

As possible to see, steels delivered in thermo-mechanically treated condition have the lowest transition temperature, and generally slightly higher values of impact toughness, particularly at lower temperatures.

\section{Conclusion}

For proper selection of structural steel for welded product, relatively complex set of design criteria must be carefully considered. Primary concern is often weight of product, and it is easily solvable by using steels with increased strength (i.e. higher grades). However, with selection of higher grades, other product conditions must be considered as well (i.e. several design criteria must be met). Principal problem is that high-strength steels may suffer from degraded toughness and ductility properties, as well as impaired weldability.

That problem is partially solved by using steels delivered in different conditions, offering various combinations of their properties. This paper presents such combinations through several selection charts comprising mechanical properties and weldability (represented as carbon equivalent, CEV).

One of conclusions of this research is that various structural steels of same quality (strength and toughness) may exhibit relatively different mechanical properties, and this is possible to see in data presented in diagrams. Data is referenced to various sources, including own researches. Possible explanation for such unusual phenomenon is that steels used in experiments are produced by different steel manufacturers. Nowadays, thermo-mechanically treated structural steels, particularly those within strength range from 355 to 460, have excellent combination of high strength, superior toughness, sufficient ductility, and good weldability.

Future researches should broaden number of parameters used in selection charts. This paper does not consider price and availability of certain structural steels, since certain steel manufacturers are able to deliver steels only in certain conditions. If future research comprehends price and availability as well, that could lead to creating set of selection charts comprising all major properties important to engineers creating and manufacturing steel products: mechanical, technological, and economical.

\section{References}

[1] Ban, H., Shi, G., Shi, Y. \& Wang, Y. (2011). Research Progress on the Mechanical Property of High Strength Structural Steels, Advanced Materials Research, Vol. 250-253, 2011, pp. 640-648.,

DOI: 10.4028/www.scientific.net/AMR.250-253.640

[2] Jenicek, S., Jirkova, H., Kucerova, L. \& Masek, B. (2011). The behaviour of low-alloy high-strength steel after different types of processing for dynamic load, Proceedings of the 22nd International DAAAM Symposium, B. Katalinic (Ed.), Vol. 22, No. 1, ISSN 1726-9679

[3] Brnic, J. (2010), Properties comparison of two constructural steels: ASTM A709 and ASTM A505, Proceedings of the 21st International DAAAM Symposium, B. Katalinic (Ed.), Vol. 21, No. 1, ISSN 1726-9679 
[4] Hradil, P. \& Talja, A. (2017). Ductility limits of high strength steels, FIMECC Research Portal, Research Report VTT-R-04741-16

[5] Bannister, A. C. (1999). Yield stress/Tensile stress ratio: Results of Experimental Programme, SINTAP - Structural Integrity Assessment Procedures for European Industry, British Steel

[6] Johansson, B. \& Collin, P. (2005). Eurocode for high strength steel and applications in construction, International Conference "Super-High Strength Steels", 2005.

[7] Hajro, I. \& Tasic, P. (2018). Properties mismatching and distribution on structural steels welded joints, Advanced Technologies and Materials, Vol. 43, No. 2, 2018, pp. 15-20., ISSN: 2620-0325, DOI: 10.24867/ATM-2018-2-003

[8] Hajro, I., Burzic, Z., Kapor, N. J. \& Kokelj, T. (2012). Experimental investigation of high-strength structural steel welds, Journal of Mechanical Engineering, Vol. 58, No. 6, 2012, pp. 422-428.

[9] Hajro, I., Hodžić, D. \& Tasić, P. (2016). Review of Strength - Toughness relationship for various structural steels grades, Journal of Trends in development of Machinery and Associated Technology, Vol. 20, No. 1, 2016, pp. 4952., ISSN 2303-4009

[10] Bannister, A. C., Skalidakis, M., Pariser, A., Langenberg, P., Salcedo, F. G.-S. \& Pesquera, L. S. D. (2006), Performance criteria for cold formed structural steels, Technical Steel Research, EC, Final Report

[11] Kuhn, B. \& Sedlacek, G. (2009). Innovative rules in Eurocode 3, Part 1-10 for the choice of materials toughness and the wide range of applicability, Proceedings of Nordic Steel Construction Conference NSCC 2009, 2009, pp. 25-32.

[12] Patel, J. (2017). The value of high strength steels, enabling low carbon energy technologies: Off-shore win farms, SEAISI Quarterly - South East Asia Iron and Steel Institute, Vol. 46, No. 4, 2017, pp. 68-75.

[13] Patel, J. K. \& Jansto, S. G. (2012). Niobium high strength steels for greener wind power generation, Millenium Steel, 2012, pp. 171-175.

[14] Hechler, O., Axmann, G. \& Donnay, B. (2009). The right choice of Steel According to Eurocode, In: Economical Bridge Solutions based on innovative composite dowels and integrated abutments, Petzek, E. \& Bancila, R. (Ed.), pp. 21-43.

[15] Liu, C. \& Bhole, S. D. (2013). Challenges and developments in pipeline weldability and mechanical properties, Science and Technology of Welding and Joining, Vol. 18, No. 2, 2013, pp. 169-181.

[16] Qiao, G., Chen, X., Zhang, Z., Han, X., Wang, X., Liao, B. \& Xiao, F. (2017). Mechanical properties of high Nb X80 steel weld pipes for the second West-to-East gas transmission pipeline project, Advances in Materials Science and Technology, Vol. 2017, 2017, DOI: https://doi.org/10.1155/2017/7409873

[17] Arai, Y., Nakamura, J., Kondo, K., Hisamune, N., Nagayama, H., Hamada, M., Hirata, H. \& Murase, T. (2015). Development of X90-X100 seamless line pipes and their application, Nippon Steel \& Sumitomo Metal Technical Report No. 107, pp. 52-58.

[18] Feldmann, M., Eichler, B., Kühn, B., Stranghöner, N., Dahl, W., Langenberg, P., Kouhi, J., Pope, R., Sedlacek, G., Ritakallio, P., Iglesias, G., Puthli, R. S., Packer, J. A. \& Krampen, J., Choice of steel material to avoid brittle fracture for hollow section structures, JRC Scientific and Policy Reports, European Commission, 2012. 